\title{
特 集：社会的に問題のある薬物
}

\section{副腎皮質ステロイド}

塩 川 優 一*

\section{はじめに}

第 1 例 慢性関節りウマチのために寝た切りに なり, 約 9 年間にわたり苦しんでいた女性がいた。 ある日新聞の広告でリウマチに有効といら健康食 の広告をみてこれを買い，3 日間飲み続けたら忽 ち症状が全く消失し元気になった。そこで思い 切って九州に旅行して楽しんで来た。この話を聞 いた友人が何か副作用はないかと聞いたら少しふ とって来たという．特そらくステロイドが入って いると思らので忠告したが, 本人は満足している. その後どうなったか知らない。

第 2 例 7 歳の女児. 急に $40^{\circ} \mathrm{C}$ の高熱を発し, 両膝関節痛を訴えた。抗生剤を投与したが軽快せ ず，ついに 3 カ月よりステロイドを投与した所下 熱した。そこでリウマチ熱，膠原病などの疑いで ステロイドを継続投与し， 1 年後には 1 日 $5 \mathrm{mg}$ を連続投与していた。

当院に受診し，入院精査したところ尿に蛋白陽 性, 腎孟撮影で变形を認め, 膠原病の疑いはなく なった．次第にステロイドを離脱したところ尿中 に大量の大腸菌排出をみた。そこで腎盂腎炎の診 断のもとに抗生剂で治療, その後 5 年にわたる経 過観察で尿に少量の蛋白をみるのみで元気に過し ている.外来受診時はステロイドによる円形顔貌, 多毛などが著明であった。

\section{ステロイドの功罪}

われわれはステロイド使用についての問題を無

\footnotetext{
$*$ 順天堂大学医学部内科
}

数に見聞している。ここではそのらちで 2 例だけ を取上げてみた，第 1 例は民間療法として健康食 といらのが流行しているが，その中に効果を上げ るため密かにステロイドを混入しているのであ る.このような薬が市販され，容易に入手し得る といら社会状況も大きな問題であるが，さらに慢 性関節リウマチのような重い病気を正規の医療を 受けずこのような方法で治療し，しかも副作用の 心配もしないという無智な患者には一驚する.

第 2 例は腎孟炎による発熱に対し，膠原病とい ら診断でステロイドを連続投与していたという例 である。このような不明の発熱の診断が難しいと いらことはよく分るとしても，もしこの少女がそ のままステロイドを続けていたらどうなったであ ろらか.そしてこのようなことは世の中に無数に 行われているのではないだろらか。

\section{ステロイドの使用状況}

副腎皮質ステロイドのきわ立った特徵は顕著な 臨床的効果がある一方, 重篤な副作用を伴うこと にある．そこで使用方法が正しければ救命的な効 果により医療に役立つが，一歩誤をると致命的な 事故に至るのである. それに加えてもう 1 つ, 本 剤には離脱困難と反跳現象ということが起こる. さらにステロイドは患者に精神的な作用があり， 多幸症が起こる．これらにより一たん使用すると なかなか中止出来なくなる，ステロイドの乱用， 誤用が社会問題となってきた大きな理由はこれら の特徵にある。それらの点について以下記してみ よ5.

ステロイドの適応は広範である，従って副作用 
Table 1 当教室に扣ける副作用の原因薬剂

\begin{tabular}{|c|c|}
\hline 剂 & 回 数 (\%) \\
\hline 非ス抗炎症剂 & $8(22.9)$ \\
\hline 抗 生 剂 & $6(17.1)$ \\
\hline 副腎皮質ステロイド & $5(14.3)$ \\
\hline ペニシラミン & $4(11.4)$ \\
\hline サルファ剂 & $4(11.4)$ \\
\hline 下熱 鎮 痛 剂 & $3(8.6)$ \\
\hline そ の 他 & 5 \\
\hline 計 & 35 回 \\
\hline
\end{tabular}

の出現も多い．われわれの教室では先年， 3 力月 間の入院患者 178 名について薬物使用に起因する 副作用を調査してみた ${ }^{1)}$ 。 その結果は 25 名 (14.0 \%）に何らかの副作用の出現をみた。 そして副作 用の全出現回数は 35 回であったから，1 人当り 1.4 回の割で発生しており, とくに 9 人では 2 回 以上の発現をみている.副作用の 35 回の内訳は表 のごとくである (Table 1). すなわち副腎皮質ス テロイドによるものは第 3 位であり，全例の 14.3 \%に当っている.ただしわれわれの教室は膠原病, アレルギー，血液など，ステロイドを使う機会の 多い疾患を専門にしていることを考慮しなければ ならない。

つぎにわれわれの教室で 108 例のステロイドを 投与した患者に怙ける副作用の出現を調査し た 。そ結果を表示する (Table 2). それによる と $67.6 \%$ に副作用の出現をみた. そしてそのうち で生命の危険を伴う可能性がある大症状は打のお の 10 例位ずつにみられている.

ステロイドは多くの疾患に用いられている。そ のらちでステロイドの功罪がもっとも問題になる のは膠原病, リウマチの場合である。それではこ れらの疾患でどの位ステロイドが使用されている であろらか. 東京都に执いて, 1163 名の classical, および definite の慢性関節リウマチ患者について ステロイド，その他の抗リウマチ剤の使用状況を 調査した ${ }^{3)}$ 。その結果は表のごとくである (Table 3).すなわち，ステロイドの投与は $40.2 \%$ に拈い て行われている，本症は慢性の疾患であるが生命
Table 2 当教室に打ける副スによる副作用 (副作用の出現率)

\begin{tabular}{|c|c|c|c|}
\hline & 副 作 用 & 副作用例数 & 出現率 (\%) \\
\hline \multirow{4}{*}{$\begin{array}{l}\text { 大 } \\
\text { 症 } \\
\text { 状 }\end{array}$} & 消化性潰瘍 & 13 & 12.2 \\
\hline & 骨粗㯲症 & 9 & 8.4 \\
\hline & 精 神 変 調 & 10 & 9.3 \\
\hline & 感 染 症 & 9 & 8.3 \\
\hline \multirow{6}{*}{ 小 } & 糖尿 & 10 & 9.3 \\
\hline & 高 血 王 & 7 & 6.5 \\
\hline & 反跳・再燃 & 13 & 12.2 \\
\hline & 円 形 顔 貌 & 42 & 38.9 \\
\hline & 浮腫 & 7 & 6.5 \\
\hline & 体重增 加 & 17 & 15.7 \\
\hline 症 & 多 & 7 & 6.5 \\
\hline \multirow{6}{*}{ 状 } & 皮唐萎縮 & 3 & 2.8 \\
\hline & 紫 & 7 & 6.5 \\
\hline & 座 & 19 & 17.6 \\
\hline & 月 経 不 順 & 16 & 14.8 \\
\hline & 白血球増加 & 5 & 4.6 \\
\hline & 合 計(108例) & 73 & 67.6 \\
\hline
\end{tabular}

Table 3 東京都に抢ける慢性関節リウマチ 患者の治療状況

\begin{tabular}{l|c|c}
\hline & Number & $\%$ \\
\hline Corticosteroid & 468 & 40.2 \\
$\begin{array}{l}\text { Non-steroidal } \\
\text { antiinflammatory }\end{array}$ & 973 & 83.6 \\
$\quad$ agents & 303 & 26.1 \\
Gold & 39 & 3.4 \\
Chloroquine & 9 & 0.8 \\
Immunosuppressive & & \\
$\quad$ agents & 80 & 6.9 \\
Physical therapy & 21 & 1.8 \\
Surgery & & \\
\hline
\end{tabular}

Total number : 1164

に対する予後は良好である. 従って生命の危険を 伴らステロイドは原則的には使用を避けることに なっている。しかしステロイドにより臨床症状に 顕著な改善をみることより止むを得ず使用するこ とが多く，一たん使用を開始すると中止は困難に なるのである。

慢性関節リウマチに拈ける使用状況から推測し 
ても，颃そらく日本全国に和けるステロイド使用 中の患者数は膨大な数に昇ると思われる. そして これがステロイド使用が社会問題になる大きな原 因といえるのである.

\section{ステロイド連続投与による問題}

ステロイドの長期にわたる投与は多くの重篤な 副作用を生ずる.ここではそのうちで major side effect とよばれる重症の副作用について説明しよ 5 .

\section{1) 消化性潰瘍}

われわれの集計ではステロイド投与例の $12 \%$ にみられたが，世界的には27\%から1\%迄種々の 報告がある。

Kammerer ら $(1958)^{4)}$ は慢性関節リウマチの症 例に括いて症状の有無に拘わらずバリウムを用い て胃レントゲン検査を行った所，ステロイド投与 例は $31 \%$, 非投与例では $9 \%$ に潰瘍を認めた。一 方慢性関節リウマチ以外に执いてはステロイド投 与によりとくに潰瘍の頻度は高くないとされてい る。そこで Spiro and Milles (1960)5) は，扔そら く慢性関節リウマチでは併用している aspirin が 原因であろらと考光た。すなわちaspirin により生 ずる粘膜のび爛がステロイドにより治療機転を妨 げられ，さらに悪化するだろらといらのである. しかし Scott ら (1961) ${ }^{6)}$ は慢性関節リウマチに招 いて， aspirin 投与例の $70 \%$ に消化管出血をみた が，ステロイド投与例では $4.5 \%$ そるのみで あった。ささらに aspirin とステロイドの併用に よっても aspirin のみの投与より出血は増加しな かった．勿論出血と潰瘍は同じ機序で起こるとは いえないが, aspirin が潰瘍の原因であり, ステロ イドがこれを助長するとはい劣ないようである。

こうして現在のところ，慢性関節リウマチにみる 消化性潰瘍は aspirin のためともステロイドのた めとも結論出来ないといら状態である.

動物実験に执いてもステロイドは出来ている消 化性潰瘍を悪化するが，発症させることはないと されている.

一方多くの臨床的経験によりステロイド投与中

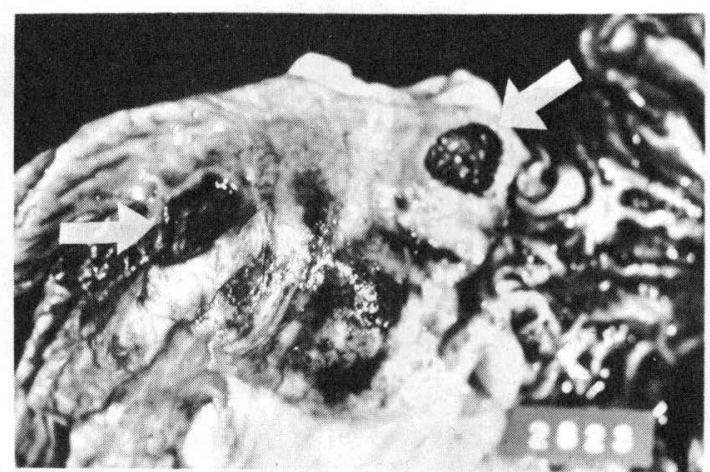

Fig. 1 全身性エリテマトーデスの十二指腸 に生じたステロイドによる消化性潰 瘍. 患者は出血のために死亡.

の患者では消化性潰瘍が生じ，これが出血，とき に穿孔を起こし, 死因となるのである (Fig. 1). そ して穿孔という点を取上げての研究が行われた が，この場合もステロイドの連続投与の例に穿孔 が多いという結論は得られなかった。ただ重要な ことは，ステロイド投与により消化性潰瘍の自覚 症状がマスクされ，知らないらちに悪化するとい ら現象である。この点でステロイド投与中は胃の $\mathrm{X}$ 線写真を反復して撮影し，しばしば便の潜血反 応をしらべる必要がある，そしてもし消化性潰瘍 が発症していれば悪化を防ぐためステロイドの減 量, 中止を考慮すべきである.また aspirin との併 用はなるべく避ける方が賢明であろろと思われ る.

\section{2) 骨粗鬆症}

ステロイド投与により起こる重篤な副作用であ る。しかも消化性潰瘍と異なり，慢性関節リウマ チでも, それ以外の疾患でも同じ頻度で発症する. われわれの集計では $8 \%$ に起こったが，さらに精 密な検査によればその頻度ははるかに高いものと 思われる。すなわら，ステロイド長期投与の患者 では全例に徐々に骨の変化が進行するものと考克 られる，そして脊椎骨の虚脱といらような臨床症 状が現れるのには数カ月かかる．尿のカルシゥム 排泄の増加がその唯一の指標である。そしてこれ は骨粗鬆症の原因がステロイドによる骨組織の分 解によることを示している. 
骨粗鬆症は男, 女ともに同率で起こり, 虚脱, 骨折の原因となる，そして脊椎，とくに胸腰椎に 多い.それが大腿骨頭に起こると歩行困難になり， 頸椎に起こると呼吸停止で死亡することになる. ただし，投与しているステロイドの種類とは関係 なく，また投与量とも関係ないとされる。

成人ではステロイド投与を中止しても骨粗鬆症 の回復は困難である.従ってX線によりしばしば ステロイド投与の既往を知ることが出来る。しか し小児では正常に戻る。な损骨粗鬆症による骨折 はステロイドの減量により回復し得る.

骨粗箖症の治療はステロイドを中止するより他 はない.この点, 全身性エリテマトーデスのよう にステロイドを中止すると生命の危険を生ずる場 合には問題がある.蛋白同化ホルモンはしばしば 治療に用いられるが，効果は認め難いことがすで に臨床的に比較検討され, 確かめられている。 たカルシゥムやビタミン D投与も効果はない。た だ痛みに対しては種々の鎮痛剤が用いられてい る.

\section{3 ) 感染症}

ステロイド投与中の患者が感染症にかかりやす いことはよく知られている，ステロイドが抗体産 生を抑制するといら報告は常用量ではない。また 細胞性免疫に拈いては，皮膚反応を低下させると いら報告はあるが，これはむしろ局所の炎症を抑 制することによるのである，すなわちステロイド により感染症が増加するのはそれによる組織の修 復力の低下が主な原因と考号いる。 またステロ イドの大量投与が行われる白血病のような場合に ははじめて免疫抑制が問題になるが，その時には おそらく同時に投与されている免疫抑制剤の影響 が大きいと思われる。

ステロイドにより起こる感染症は細菌, 真菌, ウイルス，原虫のいずれによるものもある，乙か しとくに臨床的に重要なのはウイルス, 結核菌, 真菌の3つであろう.

ウイルスでは帯状ヘルペスがしばしば問題にな る. また単純へルペス, 水痘も起こりやすくなる. さらに単純へルペスや帯状ヘルペスによる脳炎が
起こることもある．角膜の単純性へルペス感染に より失明することもみられる。ステロイド投与中 の患者に種痘を行い牛痘症を発症して死亡したと いら報告もある。従ってステロイド投与の患者で はウイルス感染症の機会はなるべく避け，また止 むを得ない時は $\gamma$ グロブリン注射を行う。

細菌感染も起こりやすく，またふだんは病原性 の少ない微生物による感染がみられる。とくにス テロイド投与中は発熱, その他の臨床症状がマス クされるので発見が遅れる。結核はとくに多くみ られ，潜在性の結核病巣がステロイド投与により 活動化する，そのために粟粒結核が起こった例も ある。

真菌ではモニリア,アスペルギルス感染があり， その他ノカルジア症, ムコルマイコージス, クリ プトコッカス症なども報告されている.

感染症に対しては早期発見に努めると共に抗生 物質の投与を行う。ただし，ステロイド投与は抗 炎症効果があるので，感染症に対しては抗生物質 を併用していればステロイド投与を中止する必要 はない。

\section{4) 精神病}

ステロイドを投与すると多幸症が起こることは よく知られている. その他不眠, 不安, 引つ状態, さらに精神病に至るらつ病はとくに自殺を招くこ とがあるので重要である。これは素因のある人に 起こりやすく，とくに慢性の疾患で悲観的な状態 に陥っている場合にはステロイド投与の間はとく に注意して監視する必要がある。

\section{ステロイド中止に伴う問題}

多くの疾患に対してステロイドの応用が行われ るようになっており，これを中止すると種々の症 状が出現することが注目されて来た，それを離脱 症候群 withdrawal syndrome とよぶ.ところでよ

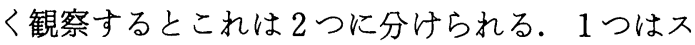
テロイド自体に起因するもので，1つは原疾患の 再発に由来するものである．この点より前者を離 脱症候群（狭義）とし，後者を反跳現象 rebound phenomenon とよぶのがふつらである. 


\section{1、ステロイド離脱症候群}

離脱症候群の純粋な形は実験的にしか得ること が出来ない.Good ら (1959) ${ }^{7}$ は健康者（病院の医 師またはその他のスタッフ） 20 名に prednisolone $40 \mathrm{mg}$ を1回のみ投与した. 29 回の実験で 11 回に何らかの下記のような症状が出現した。筋 肉痛はもっとも多く 26 回中 10 回に起こり, 部位 では下腿にみられた。 こわばりは 15 回中 6 回にみ られ，筋肉痛と同じ部位に起こった，関節痛（足 および膝）は 9 回中 3 回に起こり，さらに全身倦 怠，不快感は時に臥床を要する程であった。そし て血清 cortisol 量の測定によるとこれらの症状は 低い cortisol の濃度よりもむしろ濃度が急速に低 下する時期に著明であったという。

離脱症候群は臨床的には長期にステロイドを連 続投与した後中止する時に起こる. そしてかなり 注意深く徐々に減量してもやはり起こってくる. このような症状は投与中止後 $24 \sim 48 \mathrm{hr}$ の間に起 こり，数日で消失するが，時に数力月にわたり継 続することもある.ふつらみられるのは発熱, 悪 心, 全身倦㤐, 衰弱, 傾眠, 関節痛で, 時に虚脱 を伴うこともある．慢性関節りウマチなどでは関 節痛が再発するので反跳現象と誤られる。すでに 1957 年, Roetstein and Good ${ }^{8)}$ はこのような症状 を steroid pseudorheumatism と名づけていた。 しかしこれは原疾患が慢性関節リウマチのように 関節痛を伴う疾患でなくても起こるのである.

離脱症候群の原因としてステロイド中止による 血中 cortisol 量低下が考えられていたが, Good の実験でも明らかなよらにそれとは関係ない。を た間脳・下垂体・副腎系が正常であっても，また 血中 cortisol 量が正常であっても起こってくる. 現在での説明は，扣そらく体組織が高い血中 cortisol 量に慣れており, その低下に際し異常を示す といらのである。それはちょらど糖尿病に打いて 組織が高血糖に慣れて打り, insulin などで血糖值 が急速に低下するとまだ正常值以上であるのに低 血糖の症状を呈するのと同じだと考える. しかし な招その原因は十分説明されたとはいえない。

以上は副腎機能の低下を伴わない場合である
が，長期ステロイド投与により副腎機能が低下し た状態でも同様な症状が起こり，とくに急速な離 脱により虚脱，ついで死亡に至ることがある。た だし最近の研究では長期にわたるステロイド投与 でも，副腎機能はかなりの程度迄正常に回復する ことが分っている.しかし外科的手術などさらに ストレスが加わる場合には十分な注意が必要であ る.

\section{2. 反跳現象}

反跳現象の方は先に述べたようにステロイド投 与により抑圧されていた症状がその中止により再 び出現することである.とくに慢性関節りウマチ, 全身性エリテマトーデスなどの膠原病に拀いては その臨床症状は汪ぼ完全にステロイドにより消失 する. しかし投薬中止により再びそのすべてが出 現すると共に，一時的には以前にも増して悪化す ることがみられ，これが反跳という名のついた理 由である。このような現象は気管支喘息や慢性の 皮膚疾患にもみられ，時にそのために重篤な状態 に陥ることがある。

ただ注意すべきことは離脱症候群と反跳現象は しばしば合併して起こり，その区別は時に困難で あることである，反跳現象は出来るだけ徐々に減 量し, 最後に少量の維持量を続けることでかなり 防止出来る.

\section{ステロイド依存性}

ステロイドの離脱についてもう 1 つの重大な問 題は，ステロイドには依存性が出現することであ る，すなわちステロイドの投与は一種の多幸症を 伴う.そしてこれは病気の活動性とは関係がない。 そこでもし薬剤を中止すると強い脱力感と衰弱感 を生じ，これは耐えられない程激しいので，患者 はステロイドを求めて止まなくなる，さらにこの ような投与と中止の体験から一種の条件反射が形 成され，そしてこれに症状の悪化を伴うので患者 はステロイドなくてはいられなくなるのである. この状態は完全な薬物嗜癖といえるが，しかしそ の発症機序よりみると明らかに麻薬の場合とは性 
質を異にしている。

この状態を防ぐ方法は患者に対する反覆した, 十分な説得しかない.プラシーボを用いることは 患者がただちに見分けてしまうので失敗する。そ して止むを得なければなるべく少量のステロイド 投与で満足させるように努力すべきである.

\section{ステロイドの誤用}

つぎにステロイドの誤用について考えてみよ ら、ステロイドの適応は広範であり，これらにつ いては著効がみられることより，一種の万能薬と いった信仰が拡がっている，確かに全身性エリテ マトーデス, 皮膚筋炎, 結節性動脈周囲炎など, 放置すれば生命を失うことに決っている疾患が寛 解することはステロイドの大きな恩恵である。ま た最近に至り，不明の疾患に対しステロイドを一 応使用してみるといら考光が行われている.

われわれの経験する多くの誤用例は発熱，関節 痛を訴える患者に関するものである。まず，発熱 が長く続く場合，検索を重ねても原因不明のこと が多い。これは設備の整った大病院でもみられる のであるから，まして実地医家では診断に困る例 が多いと思われる。

このような段階に扣いて，とくに抗生剂が奏効 しない時に，ステロイドがしばしば試みられる。 そしてステロイド自身，抗炎症作用があるので必 ず或る程度迄は奏効する，そこでステロイドの減 量, 中止を試みると，必ず反跳現象が起こる，こ らして長期投与になり, 副作用が出現し, 医師も 患者も困却してしまう。

も5 1 つの場合は関節痛, 筋肉痛である.この 際もステロイドは或る程度の鎮痛効果を示すこと が多く，これは炎症に対する作用の間接的な結果 と考えられる。しかしこれは原因療法ではないか ら中止するとやはり反跳現象があり，長期投与に 入り込んでしまう。またステロイドの呈する多幸 症のため, 患者も離脱に抵抗する.

この 2 つの場合，多くは膠原病疑い，またはり ウマチ疑いといら病名がつけられている。すなわ ち, pseudo-collagen disease, または pseudo- rheumatism と名付けている状態である: このよ らな誤用に対する対策は，まず，発熱，痛みの原 因を精査し，正しく診断をつけるよう努力するこ とである.しかしどうしても診断がつかない場合 には，とくに重症でない限りステロイドを使う前 に非ステロイド性抗炎症剂を試みるべきである.

Aspirin, indomethacin, その他の非ステロイド性 抗炎症剂はステロイドには及ばないが鎮痛, 下熱, 抗炎症作用がある。 また副作用もステロイドより 軽いし，すでに日本でも数十種類の抗炎症剤が市 販されているので, 副作用出現などに際しては必 要に応じて抗炎症剂の種類を変えればよい。こう して長期にわたる同一薬剤の連用を避けることも 出来るのである。

なお，ここで一言附記して置きたいことは，ス テロイド自身によっても発熱，痛みが起こること である。

ステロイドによる発熱をステロイド熱 steroid fever とよぶ。すなわちステロイドの一種である etiocholanolone は発熱物質であり，これをヒト に注射すると発熱が起こる．われわれもこれに起 因する熱性疾患を経験している ${ }^{8)}$. 副腎皮質ステ ロイドと構造上近いが，その投与との関係は今の 所知られていない。

ステロイドの投与により筋力低下を生ずること はクッシング症候群にお括ける経験でも明らかであ る.とくにステロイドの一種, triamsinolone の投 与により筇肉に障害を呈し, 筋力低下, 筋萎縮, 筋電図変化, 生検による筋線維の変化などを示す が，これには triamsinolone が有するフッ素が関 係しているという．また，このステロイド筋症 steroid myopathy は投薬中止により速やかに回 復することが知られている。

最後に重ねていらが, 膠原病という診断はかな り難しい。しかし発熱, 関節痛のみで膠原病とい ら病名を附けることは誤りであり，この点をとく に注意して置きたい。

\section{患者の側の問題}

わが国でステロイド剂の乱用，誤用の問題が注 
目される理由はそれが以上のような医師側だけの 問題ではない所にある。すなわち，わが国では患 者側の医療，薬剤に対する関心が深く，また知識 も豊富である。これはよい面もあるがどちらかと いらと行過ぎが多く，そのために多くの社会問題 を起こしている．1つの方向は薬への頼り過ぎで あり，そのために薬を求め，無理しても入手する 傾向である，そして自分の持っている誤った知識 で自己の病気を治療するのである。リウマチに 罹ったある実業家の所へは病気見舞としてステロ イド剤が続々と送られてきていたといら例があ る。このように薬が素人に容易に入手されるとい ら所にも問題があるが，医師の指示なくしてこの ような副作用の多い薬を飲むという患者の姿勢も 理解出来ない，も51つの方向は薬に対する恐怖 症で，そのために医師の投与した薬を勝手に増量 したり，減量したりするのである，とくにステロ イドについてはこのよらな投与法はどれ位危険か ということを述べて来た，以上はすべてわが国の 医療の根本的な問題として議論しなければならな いが，ここではこれ位に止めて置く.

以上によりステロイドの副作用については医師 側が十分注意すると共に，患者をよく教育し，十 分な理解を持たせることが必要ということにな る。しかし知的に低い，また非協力的な患者に対 しては困難なことも多い。患者には病気の診断と その正確な知識を与え，これに対するステロイド の効果と副作用について十分な知識を持たせた上 で治療を開始することがもっとも望ましい。また 副作用の中でも満月様顔貌や体重増加などは止む を得ないものであること，上述のような重篤な副 作用の発現に際しては直ちに医師に申出ることな ぞを教育する，日本ではステロイドに依存し自ら 薬局，その他で入手しひそかに内服を続ける患者 がある．と共にステロイドに対して過度の恐怖心 を持って, 多少でも副作用らしいものが出現する と医師にも問わず直ちに中止し，離脱症候群に苦 しむ例がある。 また自らの症状がステロイドに起 因するのではないかと疑って中止することもあ る、いずれも非常に危険であるし，実際そのよう
Always carry this card with you and show it to any doctor whom you consult for any reason, including vaccination or inoculation.

On no account change or stop the tablets except on medical advice.

In the event of an accident, operation or sudden illness, or any condition requiring a ganeral anaesthetic, it may be necessary to alter the dose, and it is essential that the doctor should know that you are taking steroids and should see this card.

I am a patient on

S T E R O I D TR E A T M E N T which must not be stopped abrupt/y

and in the case of intercurrent illnoss may have to be increased

full datails are aveilable from the hospital or general practitioners shown overleaf

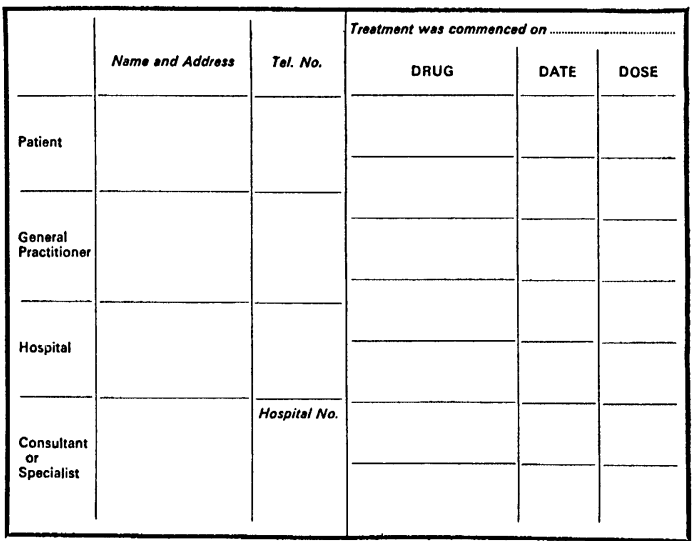

Fig. 2 アメリカで用いられている Steroid treatment card.

な例も多いのである，患者に取ってとくに理解し にくいのは自己の症状が全く消失する迄ステロイ ド量を増加することを許されない点であるから， この点よく説明しなければならない。

アメリカでは患者に対して steroid treatment card を携帯させている (Fig. 2) ${ }^{10)}$. これは患者が 他の医師にかかる時ステロイド使用中であること を証明するものである。そのようなことは旅行と か事故とか転居で起こり得るが，とくに患者が意 識障害に陷っている時はこのカードは医師に対す る唯一の貴重な情報源となり役立つのである。

おわりに

ステロイドは強力な薬効と重篤な副作用を併せ 持つ薬である。そしてその適応は広く，従って使 
用している患者数も多い。しかもステロイドには 多幸症を起こす作用があり，それを中止する時に 離脱症候群と反跳現象を生じ，それらのためにし ばしば中止が困難になる。こうしてステロイドは 社会問題を起こしつつある. 本稿では以上の点に ついて述べた。

\section{文 献}

1）塩川優一：臨床よりみた薬の安全性の問題. 薬 局, 25:869 (1974).

2）塩川優一：ステロイド治療の功罪—リウマ チ. 臨床成人病, 4:1203 (1974).

3）東京都衛生局医療福祉部：特殊疾病患者実態調 査結果. (1976).

4) Kammerer, W. H., Freiberger, R.H. and
Rivelis, A. L. : Arthritis Rheum., 1:112 (1958).

5) Spiro, H. M. and Milles, S. S. : New Engl. J. Med., 263 : 286 (1960).

6) Scott, J. T., Porter, I. H., Lewis, S. M. and Dixon, A. St. J. : Quart. J. Med., 30 : 167 (1961).

7) Good, T.A., Benton, J. W. and Kelley, V. C. : Arthritis Rheum., 2 : 299 (1959).

8) Roetstein, J. and Good, R. A. : Arch. intern. Med., 99 : 545 (1957).

9）山形寿太郎, 稗田正志, 東島利夫, 塩川優一： 代謝, $14: 939$ (1977).

10) In Corticosteroid and ACTH Treatment (Ed. A. B. Myles and J. R. Daly), Edward Arnold, Ltd, London, p. 85 (1974). 